\title{
EKSPANSI PERUSAHAAN GROUP DALAM BIDANG BATUBARA DITINJAU DARI UNDANG-UNDANG NOMOR 25 TAHUN 2007 TENTANG PENANAMAN MODAL
}

\author{
Hartana \\ Kandidat Doktor Fakultas Hukum Universitas Gadjah Mada Yogyakarta \\ Direktur Utama PT. Bumi Kencana Eka Sejahtera \\ Email : hartana_palm@yahoo.com
}

\begin{abstract}
ABSTRAK
Perusahaan group adalah suatu susunan dari perusahaan-perusahaan yang secara yuridis tetap mandiri dan yang satu dengan yang lain merupakan satu kesatuan ekonomi yang dipimpin oleh perusahaan induk.

Dalam kajian yuridis terhadap Undang-Undang Nomor 25 Tahun 2007 Tentang Penanaman Modal, terdapat pembatasan ekspansi usaha kepada penanam modal yaitu menyangkut bidang usaha dan hak atas tanah. Dalam Pasal 12, Undang-undang No. 25 Tahun 2007 tentang Penanaman Modal menjelaskan bahwa : "Pemerintah berdasarkan Peraturan Presiden menetapkan bidang usaha yang tertutup untuk penanaman modal, baik asing maupun dalam negeri, dengan berdasarkan kriteria kesehatan, moral, kebudayaan, lingkungan hidup, pertahanan dan keamanan nasional, serta kepentingan nasional lainnya".

Lebih lanjut bidang usaha ini diatur oleh Peraturan Presiden Republik Indonesia Nomor 44 Tahun 2016 Tentang Daftar Bidang Usaha Yang Tertutup dan Bidang Usaha Yang Terbuka Dengan Persyaratan di Bidang Penanaman Modal. Pada lampiran Peraturan Presiden di atas maka didapati bahwa pada Sub Sektor Energi tidak diatur mengenai kepemilikan modal, baik modal dalam negeri maupun modal asing pada sektor pertambangan batubara. Jenis bidang usaha pada sub bagian Energi hanya mengatur pembatasan kepemilikan modal asing pada sektor migas dan ketenagalistrikan.
\end{abstract}

Kata kunci : Perusahaan group, batubara, penanaman modal.

\section{ABSTRACT}

Group companies are an arrangement of companies that are juridically independent and one with another is an economic entity led by the parent company. Law of The Republic of Indonesia Number 25 of 2007 Concerning Investments, in Article 12 all business sectors or business types shall be open to investment activities, except for business sectors or business types that are declared to be closed and open with requirements, Business sectors or business types that are closed and open with requirements are provided for by Regulation of the President in a list based on the standard for classification of business sectors or business types applicable in Indonesia, to wit classification based on Klasifikasi Baku Lapangan Usaha Indonesia (KBLI) and/or the Internasional Standard for Industrial Classification (ISIC). 
Furthermore, this business field is regulated by Presidential Regulation No. 44 of 2016 on the List of Closed Business Fields and Opened Business Fields with Requirements in the Field of Investment. In the attachment of the above Presidential Regulation, it is found that the Energy Sub-Sector is not regulated on the ownership of capital, either domestic capital or foreign capital in the coal mining sector. The type of business field in the Energy sub-section only regulates restrictions on foreign capital ownership in the oil and gas and electricity sectors.

Keywords: Group companies, coal, investments.

\section{Pendahuluan}

Batubara merupakan salah satu komoditas energi penting di Indonesia. Penambangannya telah berlangsung sejak masa Kolonial Belanda. Penambangan batubara oleh Kolonial Belanda pertama kali dilakukan di Pulau Kalimantan dan Pulau Sumatera yang saat ini menjadi produsen utama batubara di Indonesia (Arif Irwandy, 2014).

Perusahaan-perusahaan yang bergerak di bidang pertambangan di Indonesia biasanya berbentuk group. Tercatat terdapat 30 group yang bergerak dalam industri pertambangan Indonesia, diantaranya adalah BUMI Plc Group, ADARO Group, BAYAN Group, INDIKA Group, BANPU Group, BA Group, BORN Group, TANITO Group, ASTRA Group, SINAR MAS Group dan masih banyak yang lainnya. Dominasi keberadaan perusahaan group dibandingkan perusahaan tunggal di Indonesia ditunjukkan oleh perusahaan-perusahaan berskala besar tidak lagi dijalankan melalui bentuk perusahaan tunggal, tetapi mengunakan konstruksi perusahaan group (Sulistiowati, 2011).

Perusahaan-perusahaan group tersebut terus melakukan ekspansi bisnisnya di sektor pertambangan batubara. Tentu saja tujuannya adalah untuk memperoleh laba atas investasinya dan memberikan sumbangan pada peningkatan ekonomi dan sosial lingkungan yang lebih luas. Untuk mencapai tujuannya, perusahaan-perusahaan group tersebut menghadapi persaingan yang semakin ketat dari pesaing-pesaing yang mempunyai tujuan yang sama, dengan produk yang ditawarkan serta cara-cara yang hampir sama pula.

Adapun cara yang dapat digunakan untuk membentuk perusahaan group adalah dengan melakukan merger, akuisisi atau membentuk perusahaan baru. Perusahaan-perusahaan

melakukan ekspansi melalui merger, akuisisi atau membentuk perusahaan baru dengan maksud dapat mengurangi perusahaan pesaing atau mengurangi persaingan. Selain itu, ekspansi melalui merger, akuisisi atau membentuk perusahaan baru akan mendorong perusahaan memiliki jenis usaha yang lebih besar tanpa harus melakukannya dari awal.

Sebagai salah satu komoditi energi yang bernilai strategis bagi kepentingan nasional, pengelolaan industri pertambangan batubara harus mengacu pada Pasal 33 
Undang-undang Dasar (UUD) 1945 yang mengamanatkan penguasaan negara atas sumber-sumber alam strategis dan berkaitan dengan hajat hidup orang banyak. Ini juga termasuk orientasi dari pemanfaatan sumber daya alam, yakni demi sebesar-besarnya kemakmuran rakyat. Pasal 33 UUD 1945 menyebutkan

"Cabang-cabang produksi yang penting bagi negara dan yang menguasai hajat hidup orang banyak dikuasai oleh negara; dan Bumi dan air dan kekayaan alam yang terkandung di dalamnya dikuasai oleh negara dan dipergunakan untuk sebesar-besar kemakmuran rakyat".

Akan tetapi, fakta di lapangan menunjukkan bahwa pengelolaan industri pertambangan batubara (termasuk sumber daya alam strategis) di Indonesia seperti mengabaikan keberadaan pasal 33 UUD 1945 tersebut. Padahal, pasal 33 UUD 1945 adalah warisan para founding fathers guna mengatur perekonomian nasional. Salah satu bukti yang menunjukkan hal tersebut tampak pada sektor hulu industri pertambangan batubara yang dikuasai oleh perusahaan swasta nasional maupun luar negeri, bukan oleh Negara atau perusahaan Negara (BUMN).

Kementerian ESDM mencatat bahwa $71,7 \%$ produksi batubara Indonesia dikuasai oleh perusahaan swasta nasional dan sisanya perusahaan asing (http://www.berdikarionline.com) . Bila dicermati, tiga angka dalam pasal 33 UUD 1945 (pra- amandemen 2002), kiprah pihak swasta nasional (maupun asing) dalam industri strategis negara sama sekali tidak dilarang. Namun, bila modal swasta nasional maupun asing sudah begitu dominan menguasai cabang-cabang produksi vital negara, hal itulah yang melanggar pasal 33 UUD 1945 secara substansial.

Perlu dipahami bahwa pasal 33 UUD 1945 merupakan buah pikir para pendiri negara yang menginginkan bangsa ini berjalan di atas kepentingan Indonesia yang berasas kekeluargaan dengan tujuan menciptakan masyarakat yang adil dan makmur beserta seluruh perangkatnya dibentuk untuk menjalankan amanat itu demi tercapainya tujuan nasional. Sementara itu, perusahaan swasta yang sedari awal didirikan dengan maksud mencari profit sebesarbesarnya tidaklah dapat dipercaya untuk mengelola sumber-sumber ekonomi strategis negara demi kemakmuran rakyat.

Penguasaan pihak swasta terhadap industri batubara nasional mengakibatkan alokasi hasil operasi produksi tambang terhitung kecil bagi kepentingan nasional. Untuk itulah pada tanggal 12 Januari 2009 Pemerintah Indonesia menerbitkan UndangUndang Nomor 4 Tahun 2009 Tentang Pertambangan Mineral dan Batubara untuk menggantikan Undang-undang Nomor 11 Tahun 1967 tentang KetentuanKetentuan Pokok Pertambangan yang dinilai sudah tidak relevan lagi untuk digunakan. Di dalam Undang-Undang Nomor 4 Tahun 
2009 dengan jelas dikatakan bahwa sumber daya alam yang telah diambil harus diprioritaskan terlebih dahulu untuk kebutuhan industri pengolahan dalam negeri atau lebih dikenal dengan istilah Domestic Market Obligation (DMO). DMO diatur secara khusus dalam Peraturan Menteri Energi dan Sumber Daya Mineral No. 34 Tahun 2009 tentang Pengutamaan Pemasokan Kebutuhan Mineral dan Batubara Untuk Kepentingan Dalam Negeri. Badan Usaha Pertambangan Mineral dan Batubara (BUPMB) yang terdiri dari pemegang Kontrak Karya (KK), Perjanjian Karya Pengusahaan Pertambangan Batubara (PKP2B), dan Izin Usaha Pertambangan (IUP) wajib memenuhi kebutuhan industri pengolahan dalam negeri. BUPMB harus menjual mineral atau batubara yang telah diproduksinya kepada Pemakai Mineral Dalam Negeri (PMDN) atau Pemakai Batubara Dalam Negeri (PBDN). Penanaman Modal adalah segala bentuk kegiatan menanam modal, baik oleh penanam modal dalam negeri maupun penanam modal asing untuk melakukan usaha di wilayah Negara Republik Indonesia.

Di Indonesia, Penanaman Modal Asing pada mulanya diatur dalam Undang-Undang Nomor 1 Tahun 1967 tentang Penanaman Modal Asing yang diundangkan pada tanggal 10 Januari 1967, pengaturannya diperbaharui dengan Undang-Undang Nomor 11 Tahun 1970 tentang perubahan dan tambahan, dan kemudian diperbaharui lagi dengan Undang-
Undang Nomor 25 Tahun 2007 tentang Penanaman Modal yang diundangkan pada tanggal 26 April 2007, serta diatur dengan Peraturan Presiden No.77 tahun 2007 tentang daftar bidang usaha yang tertutup dan bidang usaha yang terbuka dengan persyaratan dibidang Penanaman Modal sebagaimana Peraturan Presiden Nomor 111 tahun 2007 tentang perubahan peraturan atas Persetujuan Presiden Nomor 77 tahun 2007 tentang daftar bidang usaha yang tertutup dalam bidang usaha yang terbuka dengan persyaratan dibidang Penanaman Modal , berkaitan dengan Peraturan Kepala Badan Koordinasi Penanaman Modal Nomor 12 Tahun 2009 tentang Pedoman dan tata cara permohonan Penanaman Modal, dan Peraturan Presiden Nomor 36 Tahun 2010 tentang Daftar bidang usaha tertutup dan terbuka tentang pasar modal.

Untuk badan usaha yang berstatus sebagai penanaman modal asing, pembentuk undangundang mensyaratkan badan usahanya berbentuk hukum Perseroan Terbatas (PT) (Sentosa Sembiring, Hukum Investasi. Pembahasan dilengkapi dengan Undang-Undang no 25 Tahun 2007 Tentang Penanaman Modal. Dalam penulisan ini akan di bahas berkenaan dengan Ekspansi Perusahaan Group Dalam Bidang Batubara Ditinjau Dari UndangUndang Nomor 25 Tahun 2007 Tentang Penanaman Modal. 


\section{Pengertian Perusahaan Group}

Perusahaan group memiliki peran yang semakin penting dalam kegiatan usaha di Indonesia. Perusahaan group menjadi bentuk usaha yang paling banyak dipilih oleh pelaku usaha di Indonesia. Perusahaan group adalah suatu susunan dari perusahaanperusahaan yang secara yuridis tetap mandiri dan yang satu dengan yang lain merupakan satu kesatuan ekonomi yang dipimpin oleh perusahaan induk (Simanjuntak, 2008).

Fenomena tentang adanya perusahaan-perusahaan yang bergabung dan terikat satu sama lain dalam satu consern tumbuh pada dasawarsa terakhir baik dalam skala nasional maupun dalam skala internasional. Perusahaan kelompok atau group dapat disusun secara vertikal dan horizontal. Perusahaan group disusun secara vertikal dapat dikatakan ada apabila perusahaanperusahaan yang terkait di dalam susunan itu merupakan mata rantai dari perusahaan-perusahaan yang melakukan suatu proses produksi. Perusahaan-perusahaan itu masing-masing mengusahakan lanjutan dari usaha perusahaan lain, misalnya perusahaan pertama memulai dari bahan baku, dilanjutkan ke perusahaan lain untuk mengolah menjadi bahan setengah jadi, dilanjutkan lagi ke perusahaan lain menjadi produksi terakhir untuk konsumen dan pemasarannya diusahakan oleh perusahaan lain. Semua perusahaan yang terkait itu merupakan satu kesatuan dalam perusahaan group.

Perusahaan group yang disusun secara horizontal adalah perusahaan-perusahaan yang masing-masing bergerak dalam bidang-bidang usaha yang sangat beragam. Perusahaan-perusahaan yang tersusun secara terkait satu sama lain tidak hanya menangani produksi tertentu dalam arti satu jenis tertentu melainkan berbagai jenis produksi, misalnya produksi pertanian, industri, perdagangan, jasa angkutan perhotelan, bank dan asuransi. Jadi, terdapat diversifikasi usaha dan sering dikenal dengan sebutan konglomerat.

Keberadaan dan pengakuan yuridis terhadap perusahaan group menjadi salah satu perdebatan yang telah berlangsung lama serta melibatkan berbagai wilayah yuridiksi yang berbeda. Perbedaan pendapat mengenai pengertian yuridis terhadap status badan hukum ini bersumber dari belum adanya pengakuan yuridis terhadap status badan hukum dari perusahaan group. Bahkan, realitas bisnis terkini yang ditandai oleh dominasi perusahaan group dibandingkan dengan bentuk perusahaan yang lain ternyata belum dapat menjadi justifikasi atas pengakuan yuridis terhadap perusahaan group sebagai suatu badan hukum tesendiri sebagaimana bentuk-bentuk organisasi perusahaan lain seperti perseroan terbatas (Sulistiowati, 2013).

Belum adanya pengakuan yuridis terhadap status badan 
hukum dari perusahaan group menyebabkan peraturan perundang-undangan tidak mengatur mengenai konstruksi perusahaan group. Sebaliknya, perusahaan perundang-undangan masih menggunakan pendekatan perseroan tunggal dari perseroanperseroan yang menjadi konstituen perusahaan group, sehingga peraturan perundang-undangan masih mempertahankan pengakuan yuridis formal dari status badan hukum induk dan anak perusahaan. Keterkaitan induk dan anak perusahaan dalam konstruksi perusahaan group tidak menghapuskan kemandirian yuridis dari status badan hukum induk dan anak perusahaan, walaupun anak perusahaan tunduk di bawah kendali induk perusahaan (Sulistiowati, 2013;39).

Apabila dibandingkan dengan hukum perseroan, hukum perusahaan group menangani gejala khusus dari tersusunnya perusahaan-perusahaan yang secara yuridis mandiri dalam suatu susunan yang erat antara satu sama lain, sehingga dari sudut pandang ekonomi dipandang sebagai suatu kesatuan yang berada di bawah pimpinan sentral. Perusahaan group merupakan suatu kesatuan ekonomi yang tersusun dari perusahaan-perusahaan berbadan hukum mandiri yang dipandang sebagai induk dari anak perusahaan (Sulistiowati, 2013;40).

Sesuai dengan peruntukan hukum perseroan sebagai kerangka pengaturan bagi perseroan tunggal, terhadap induk dan anak perusahaan yang berbentuk perseroan terbatas berlaku prinsip hukum yang sama dengan perseroan tunggal, yaitu perseroan sebagai subjek hukum mandiri dan berlakunya limited liability (Gazur,;1995) pada pemegang saham. Hukum perseroan sebagai kerangka pengaturan perseroan tunggal tidaklah mengatur konstruksi perusahaan group, tetapi mengatur keterkaitan antara induk dan anakanak perusahaan sebagai hubungan diantara badan hukum mandiri. Implikasi dari digunakannya hukum perseroan untuk mengatur keterkaitan antara badan hukum induk dan anak perusahaan adalah bentuk jamak secara yuridis dalam perusahaan group.

Sebaliknya pengakuan yuridis terhadap kemandirian dari badan hukum induk dan anak perusahaan menimbulkan komplikasi permasalahan hukum yang terkait dengan perusahaan group. Kepemilikan saham induk pada anak perusahaan, penempatan direksi pada anak perusahaan, maupun kontrak bersuara menjadi alasan keberadaan bagi timbulnya keterkaitan antara induk dan anak perusahaan. Induk perusahaan memiliki kewenangan untuk bertindak sebagai pimpinan sentral, yang mengendalikan dan mengkoordinasikan anak-anak perusahaan dalam suatu tatanan manajemen untuk mendukung tujuan kolektif perusahaan group sebagai satu kesatuan ekonomi.

Kerangka pengaturan mengenai keterkaitan induk dan 
anak perusahaan yang menggunakan pendekatan perseroan tunggal menimbulkan kontradiksi dengan realitas bisnis perusahaan group yang ditandai oleh adanya pengendalian induk terhadap anak perusahaan. Penyebab timbulnya kontradiksi ini adalah legitimasi peraturan perundang-undangan terhadap munculnya realitas kelembagaan perusahaan group. Peraturan perundang-undangan mengizinkan suatu perseroan melakukan perbuatan hukum untuk memiliki maupun memperoleh saham pada perseroan lain, baik melalui pendirian perseroan lain pengambilalihan saham perusahaan lain, maupun pemisahan usaha. Kepemilikan saham suatu perseroan pada perseroan lain menjadi sebab timbulnya keterkaitan induk dan anak perusahaan, sehingga induk perusahaan memiliki kekuasaan untuk bertindak sebagai pimpinan sentral yang mengendalikan dan mengkoordinasikan anak-anak perusahaan dalam mendukung tercapainya tujuan kolektif perusahaan group sebagai satu kesatuan ekonomi.

Penjabaran di atas menunjukkan bahwa komplikasi permasalahan dalam perusahaan group bersumber dari dimasukkannya konsepsi pengendalian induk terhadap anak perusahaan ke dalam ranah hukum perseroan. Hal ini menimbulkan kontradiksi dengan prinsip hukum umum yang berlaku mengenai kemandirian badan hukum induk dan anak perusahaan. Pengakuan yuridis terhadap badan hukum induk dan anak perusahaan sebagai subyek hukum mandiri menyebabkan induk dan anak perusahaan berhak melakukan perbuatan hukum sendiri, sedangkan ada fakta pengendalian induk terhadap anak perusahaan dari realitas bisnis perusahaan group yang dikelola sebagai satu kesatuan ekonomi. Pengendalian induk terhadap anak perusahaan dalam konstruksi perusahaan group menimbulkan dualitas pada anak perusahaan, yaitu sebagai badan hukum yang mandiri dan badan usaha yang tunduk di bawah kendali induk perusahaan.

\section{Tinjauan Umum Ekspansi Perusahaan}

Perusahaan harus melakukan usaha terobosan agar kontinuitas kehidupannya dapat dipertahankan yaitu melalui investasi pengembangan usaha atau lebih sering dikenal dengan sebutan ekspansi perusahaan. Ekspansi merupakan manifestasi dari keinginan untuk mempertahankan keberadaan perusahaan dalam jangka waktu yang panjang. Perusahaan tidak didirikan dengan maksud untuk berhenti setelah mendapatkan keuntungan sementara. Ekspansi dilakukan untuk memberikan pertumbuhan bagi perusahaan. Ekspansi adalah memperbesar perusahaan baik dengan jalan mendirikan usaha baru dengan produk baru ataupun produk yang sudah ada ditempat lain ataupun juga meningkatkan produksi barang yang telah diproduksi. 


\begin{abstract}
Perusahaan yang ingin mempertahankan

keberlangsungan hidupnya harus peka terhadap peluang dan ancaman yang ada. Hal ini dimaksudkan sebagai bagian dari upaya untuk mencapai kehidupan perusahaan yang lebih baik dengan cara memenuhi kebutuhan konsumen. Bambang Riyanto menerangkan dalam konteks ekspansi, ada dua motif utama yang mendasari suatu perusahaan melakukan ekspansi, yaitu motif ekonomi dan motif psikologis. Mengenai kedua motif tersebut diuraikan sebagai berikut (Bambang Riyanto, 1999;231):
\end{abstract}

1. Motif Ekonomi

Apabila ekspansi suatu perusahaan didasarkan pada pertimbangan untuk memperbesar atau menstabilisir laba yang diperoleh. Hal ini terjadi misalnya karena semakin besarnya permintaan terhadap produk atau jasa yang diproduksi oleh suatu perusahaan. Makin besarnya jumlah produksi yang dapat dijual, berarti semakin besar kemungkinan untuk mendapatkan laba yang lebih besar, sehingga dengan demikian setiap pimpinan perusahaan mempunyai harapan dan keinginan untuk dapat selalu mengembangkan dan meluaskan perusahaan.

Dorongan tersebut adalah wajar karena perusahaan untuk dapat mempertahankan dan bahkan mengembangkan keberadaan perusahaan haruslah memperoleh keuntungan. Keuntungan yang diperoleh perusahaan mempunyai beberapa fungsi atau kegunaan antara lain sebagai berikut:
a. Alat pengukur prestasi perusahaan.
b. Dapat dipergunakan untuk memenuhi kewajiban- kewajiban perusahaan.
c. Sebagai sumber dana perusahaan.

2. Motif Psikologis

Ekspansi yang dilakukan dalam kategori motif psikologis semacam ini seringkali atau bahkan tidak melakukan perhitungan ekonomis terdahulu. Ekspansi ini didasarkan pada personal ambition dari pemilik atau pimpinan perusahaan untuk memperoleh prestige dan kekuasaan yang lebih besar. Hal yang menonjol dari motif psikologis adalah lebih didorong oleh insting atau judgement berupa keberanian untuk mengambil resiko meskipun tanpa didukung oleh pertimbangan rasionalitas yang matang.

Dengan demikian, ekspansi merupakan suatu bentuk perluasan usaha baik dalam meningkatkan komponen aktiva lancar, aktiva tetap atau lainnya sebagai motif yang meningkatkan nilai ekonomi maupun personal ambition dari pimpinan perusahaan untuk mencapai suatu tujuan.

\section{Penanaman Modal Menurut Undang Undang Nomor 25 Tahun 2007}

Ditetapkannya ketentuan penanaman modal melalui Undangundang tentang penanaman modal Nomor 25 Tahun 2007 sebagai pengganti Undang- Undang Nomor 
1 Tahun 1967 tentang Penanaman Modal Asing dan Undang- Undang Nomor 6 Tahun 1967 tentang Penanaman Modal Dalam Negeri telah mengakhiri dualisme pengaturan tentang penanaman modal. Selain itu, kehadiran undang-undang yang baru ini sekaligus mempertegas dan memperjelas kebijakan pengaturan penanaman modal di Indonesia. (Sri Yuliati, Analisis Hukum Tentang Pemilikan Saham Pada Perusahaan Penanaman Modal Asing).

Undang-Undang Nomor 25 Tahun 2007 tentang Penanaman Modal memberikan ketentuan terhadap investor asing yang akan menanamkan modalnya (melakukan kegiatan usaha) di Indonesia harus mendirikan badan usaha yang berbentuk perseroan terbatas (PT), juga karena para usahawan itu sendiri yang memilih untuk mendirikan badan usaha yang berbentuk perseroan terbatas (PT) dalam melakukan aktivitas usahanya. Pemilihan itu tentunya bukan tidak beralasan karena PT sebagai bentuk badan usaha dirasa mempunyai kelebihan dibanding badan usaha lainnya (Agus Budiarto,2002;13).

$$
\text { Salah satu tujuan }
$$

pembentukan pemerintahan negara adalah untuk memajukan kesejahteraan umum. Amanat tersebut, antara lain, telah dijabarkan dalam Pasal 33 UndangUndang Dasar Negara Republik Indonesia Tahun 1945 dan merupakan amanat konstitusi yang mendasari pembentukan seluruh peraturan perundang-undangan di bidang perekonomian. Konstitusi mengamanatkan agar pembangunan ekonomi nasional harus berdasarkan prinsip demokrasi yang mampu menciptakan terwujudnya kedaulatan ekonomi Indonesia. Keterkaitan pembangunan ekonomi dengan pelaku ekonomi kerakyatan dimantapkan lagi dengan Ketetapan Majelis Permusyawaratan Rakyat Republik Indonesia Nomor XVI Tahun 1998 tentang Politik Ekonomi Dalam Rangka Demokrasi Ekonomi sebagai sumber hukum materiil. Dengan demikian, pengembangan penanaman modal bagi usaha mikro, kecil, menengah, dan koperasi menjadi bagian dari kebijakan dasar penanaman modal (Penjelasan Undang-Undang Nomor 25 Tahun 2007).

Berkaitan dengan hal tersebut, penanaman modal harus menjadi bagian dari penyelenggaraan perekonomian nasional dan ditempatkan sebagai upaya untuk meningkatkan pertumbuhan ekonomi nasional, menciptakan lapangan kerja, meningkatkan pembangunan ekonomi berkelanjutan, meningkatkan kapasitas dan kemampuan teknologi nasional, mendorong pembangunan ekonomi kerakyatan, serta mewujudkan kesejahteraan masyarakat dalam suatu sistem perekonomian yang berdaya saing.

Tujuan penyelenggaraan penanaman modal hanya dapat tercapai apabila faktor penunjang yang menghambat iklim penanaman modal dapat diatasi, 
antara lain melalui perbaikan koordinasi antarinstansi Pemerintah Pusat dan daerah, penciptaan birokrasi yang efesien, kepastian hukum di bidang penanaman modal, biaya ekonomi yang berdaya saing tinggi, serta iklim usaha yang kondusif di bidang ketenagakerjaan dan keamanan berusaha. Dengan perbaikan berbagai faktor penunjang tersebut, diharapkan realisasi penanaman modal akan membaik secara signifikan.

Undang-Undang ini mencakupi semua kegiatan penanaman modal langsung di semua sektor. UndangUndang ini juga memberikan jaminan perlakuan yang sama dalam rangka penanaman modal. Selain itu, Undang-Undang ini memerintahkan agar Pemerintah meningkatkan koordinasi antarinstansi Pemerintah, antarinstansi Pemerintah dengan Bank Indonesia, dan antarinstansi Pemerintah dengan pemerintah daerah. Koordinasi dengan pemerintah daerah harus sejalan dengan semangat otonomi daerah. Pemerintah daerah bersama-sama dengan instansi atau lembaga, baik swasta maupun Pemerintah, harus lebih diberdayakan lagi, baik dalam pengembangan peluang potensi daerah maupun dalam koordinasi promosi dan pelayanan penanaman modal. Pemerintah daerah menjalankan otonomi seluas-luasnya untuk mengatur dan mengurus sendiri urusan penyelenggaraan penanaman modal berdasarkan asas otonomi daerah dan tugas pembantuan atau dekonsentrasi. Oleh karena itu, peningkatan koordinasi kelembagaan tersebut harus dapat diukur dari kecepatan pemberian perizinan dan fasilitas penanaman modal dengan biaya yang berdaya saing. Agar memenuhi prinsip demokrasi ekonomi, UndangUndang ini juga memerintahkan penyusunan peraturan perundangundangan mengenai bidang usaha yang tertutup dan yang terbuka dengan persyaratan, termasuk bidang usaha yang harus dimitrakan atau dicadangkan bagi usaha mikro, kecil, menengah, dan koperasi.

\section{Pembahasan \\ Pengaturan \\ Pembatasan \\ Ekspansi Perusahaan Group di Sektor Pertambangan Batubara}

Perkembangan hukum

pertambangan di Indonesia sebenarnya sudah terlihat sejak peninggalan zaman Kerajaan Hindu Sriwijaya dan masa kerajaan Majapahit. Hal tersebut ditandai dengan banyaknya pengrajin perkakas logam pada saat itu yang dikenal sebagai zaman perunggu (Hayati, 2012;72).

Pada zaman Kerajaan Sriwijaya dan Majapahit, izin pengusahaan pertambangan yang diberikan oleh Raja atau pembesar kerajaan masih dalam bentuk lisan atau dalam bentuk tertulis di pelepah lontar. Namun hingga kini belum pernah ditemukan catatan tertulis tentang hal tersebut, karena pada saat itu yang berlaku adalah hukum adat, dengan konsep maro atau bagi hasil. Kedua konsep tersebut sampai saat ini digunakan sebagai rujukan kerjasama pengusahaan 
migas dengan kontraktor asing. Sejak kedatangan bangsa Belanda, izin pengusahaan pertambangan diberikan dalam bentuk konsesi pertambangan. Konsesi pertama kali diberikan kepada Pangeran Hendrik dan Baron Van Tyl pada tahun 1850, untuk penambangan Timah di Pulau Belitung, yang sepuluh tahun kemudian dibentuklah Perusahaan Timah Biliton Maatschappij. Konsesi merupakan bentuk izin dari produk Belanda yang pernah berlaku di Hindia Belanda (Hayati, 2012;72).

Konsesi tersebut tertuang di dalam Indische Mijnwet 1899 yaitu Undang-undang Pertambangan Hindia Belanda yang pertama dibentuk. Kemudian di tahun 1906, Undang-undang tersebut ditambah dan diubah dengan Mijnordonantie (Ordonansi Pertambangan). Peraturan ini menyatakan bahwa pemerintah mengatur perizinan perminyakan dan pertambangan bahan galian logam, batubara, batu permata dan beberapa bahan galian penting. Bahan galian yang dianggap kurang penting, seperti gamping, pasir dan lempung, perizinannya diatur oleh para pengusaha setempat, seperti Residen atau pejabat yang diberi wewenang.

Pengusahaan pertambangan di Hindia Belanda dilaksanakan oleh pemerintah dan swasta. Beberapa tambang yang dinilai sangat vital dimiliki dan diusahakaan oleh Pemerintah Hindia Belanda sendiri, seperti misalnya tambang batubara Ombilin, tambang batubara Bukit Asam dan tambang timah Bangka. Beberapa tambang yang lain diusahakan secara patungan antara Pemerintah Hindia Belanda dan Swasta, seperti tambang timah Belitung dan Singkep. Ada pula yang kepemilikannya ditangan pemerintah Hindia Belanda tetapi pengusahaannya diserahkan kepada pihak swasta berdasarkan kontrak, seperti tambang belerang Kawah Putih. Kebanyakan pihak swasta yang mengusahakan pertambangan Hindia Belanda atas dasar konsesi pertambangan yang memberikan keleluasaan besar kepada pihak pengusaha.

Untuk beberapa proyek besar seperti tambang nikel di Sulawesi Tenggara, pihak swasta mendapatkan hak pengusahaan penyelidikan dan penambangan berdasarkan kontrak khusus dari pemerintah yang disebut dengan $5 a$ contract, didasarkan pada ketentuan Pasal 5a Indische Mijnwet. Disamping perusahaan besar, banyak pula perusahaan kecil dan perorangan setempat yang melakukan penggalian bahan tambang dalam ukuran terbatas dan seizin pengusaha setempat, dengan sebutan tambang rakyat (volksontginningen). Sampai akhir tahun 1938 jumlah konsesi dan izin pertambangan lainnya yang masih berlaku tidak kurang dari 471 buah (Hayati, 2012;9).

Sejak kemerdekaan sampai tahun 1949 tidak banyak penambahan kegiatan pertambangan di Indonesia. Segera setelah penyerahan kedaulatan dari pihak Belanda pada akhir tahun 1949, Pemerintah Indonesia mulai membenahi urusan pertambangan yang sudah sangat 
terbengkalai. Selama kurun waktu tahun 1950 sampai 1965 keadaan politik di dalam negeri tidak stabil. Gangguan keamanan dan pemberontakan timbul di berbagai daerah. Akhirnya pada Juli 1959 keluarlah Dekrit Presiden "kembali ke Undang-undang Dasar 1945". Sejak saat tersebut, dimulai kehidupan demokrasi terpimpin yang melahirkan kebijakan ekonomi terpimpin dan etatisme yang menghendaki semua kegiatan ekonomi penting dikelola sendiri oleh negara.

Walaupun demikian, Pemerintah tidak mempunyai dana yang diperlukan untuk melaksanakan rencana pembangunan ekonomi. Pada saat itu sebenarnya telah ada Undangundang Nomor 78 Tahun 1958 tentang Penanaman Modal. Namun, dalam situasi demokrasi terpimpin, dibentuklah Undang-undang Nomor 37 Tahun 1960 tentang Pertambangan, yang memuat aturan untuk tidak memberikan dorongan kepada pihak swasta turut serta dalam bidang pertambangan. Hal itu juga diperparah oleh Pasal 3 Undangundang Nomor 78 Tahun 1958 yang menetapkan bahwa perusahaan-perusahaan

pertambangan bahan galian vital tertutup bagi modal asing. Pada akhirnya Undang-undang Nomor 37 Tahun 1960 tidak berhasil mendorong tumbuhnya pengusahaan pertambangan Indonesia.

Pasca lahirnya Undang-undang Nomor 1 Tahun 1967 tentang Penanaman Modal Asing, lahirlah babak baru dalam usaha pengembangan potensi pertambangan di Indonesia yang dimulai dengan dibentuknya Undang-undang Nomor 11 Tahun 1967 tentang Ketentuan-ketentuan Pokok Pertambangan. Selanjutnya sebagai peraturan pelaksanaan dari Undang-undang Nomor 11 Tahun 1967 dibentuklah Peraturan Pemerintah Nomor 32 Tahun 1969 tentang Pelaksanaan Undangundang Nomor 11 Tahun 1967 tentang Ketentuan-ketentuan Pokok Pertambangan. Ketentuanketentuan tersebut telah berhasil menciptakan iklim usaha yang cukup baik bagi kegiatan pertambangan di Indonesia. Pada akhirnya hal tersebut berhasil menarik minat investor asing untuk menanamkan modalnya di Indonesia.

\section{Ekspansi Perusahaan Group Ditinjau Dari Undang-Undang Nomor 25 Tahun 2007 Tentang Penanaman Modal}

Banyak Negara yang melakukan kebijaksanaan yang bertujuan untuk meningkatkan investasi pada Negara tersebut. Bahkan kalaupun diperkirakan modal dalam negeri kurang mampu meningkatkan investasi, pemerintah tidak segansegan mengundang pihak asing untuk melakukan investasi pada Negara itu dikarenakan kegiatan investasi akan mendorong pula kegiatan ekonomis suatu Negara.

Di Indonesia, investasi atau penananaman modal diatur dalam Undang-undang No. 25 Tahun 2007 
tentang Penanaman Modal. Penanaman modal adalah segala bentuk kegiatan menanam modal, baik oleh penanam modal dalam negeri maupun penanam modal asing untuk melakukan usaha di wilayah negara Republik Indonesia. Penanaman modal sendiri dapat dibedakan menjadi 2 (dua) bagian, yaitu (Pasal 1 Butir 1, 2 dan 3, Undang-undang No 25 Tahun 2007)

a. Penanaman modal dalam negeri, adalah kegiatan menanam modal untuk melakukan usaha di wilayah negara Republik Indonesia yang dilakukan oleh penanam modal dalam negeri dengan menggunakan modal dalam negeri.

b. Penanaman modal asing, adalah kegiatan menanam modal untuk melakukan usaha di wilayah negara Republik Indonesia yang dilakukan oleh penanam modal asing, baik yang menggunakan modal asing sepenuhnya maupun yang berpatungan dengan penanam modal dalam negeri.

Ada perbedaan dalam bentuk badan usaha antara penanaman modal usaha dalam negeri dengan penanaman modal usaha asing, yaitu (Pasal 5, Undang-undang No. 25 Tahun 2007) :

a. Penanaman modal dalam negeri dapat dilakukan dalam bentuk badan usaha yang berbentuk badan hukum, tidak berbadan

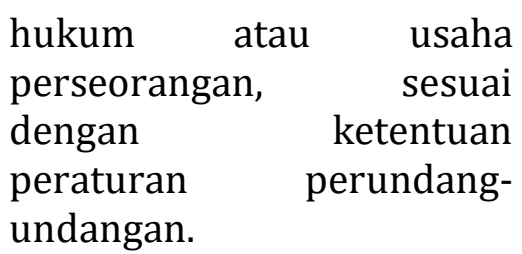

b. Penanaman modal asing wajib dalam bentuk perseroan terbatas berdasarkan hukum Indonesia dan berkedudukan di dalam wilayah negara Republik Indonesia, kecuali ditentukan lain oleh undang-undang.

Dalam menjalankan kegiatannya, pemerintah memberikan perlakuan yang sama kepada semua penanam modal yang berasal dari negara manapun yang melakukan kegiatan penanaman modal di Indonesia sesuai dengan ketentuan peraturan perundang-undangan. Akan tetapi, perlakukan ini tidak berlaku bagi penanam modal dari suatu negara yang memperoleh hak istimewa berdasarkan perjanjian dengan Indonesia (Pasal 6, Undang-undang No. 25 Tahun 2007).

Penanam modal dalam negeri dan penanam modal asing yang melakukan penanaman modal dalam bentuk perseroan terbatas dilarang membuat perjanjian dan/atau pernyataan yang menegaskan bahwa kepemilikan saham dalam perseroan terbatas untuk dan atas nama orang lain. Dalam hal penanam modal dalam negeri dan penanam modal asing membuat perjanjian dan/atau pernyataan tersebut, maka perjanjian dan/atau pernyataan itu dinyatakan batal demi hukum. 
Dalam hal penanam modal yang melaksanakan kegiatan usaha berdasarkan perjanjian atau kontrak kerja sama dengan Pemerintah melakukan kejahatan korporasi berupa tindak pidana perpajakan, penggelembungan biaya pemulihan, dan bentuk penggelembungan biaya lainnya untuk memperkecil keuntungan yang mengakibatkan kerugian negara berdasarkan temuan atau pemeriksaan oleh pihak pejabat yang berwenang dan telah mendapat putusan pengadilan yang berkekuatan hukum tetap, Pemerintah mengakhiri perjanjian atau kontrak kerja sama dengan penanam modal yang bersangkutan.

Dalam kajian yuridis terhadap Undang-Undang Nomor 25 Tahun 2007 Tentang Penanaman Modal, penulis menemukan terdapat pembatasan ekspansi usaha kepada penanam modal yaitu menyangkut bidang usaha dan hak atas tanah.

a. Bidang Usaha

Dalam Pasal 12, Undangundang No. 25 Tahun 2007 tentang Penanaman Modal menjelaskan bahwa:

"Pemerintah berdasarkan Peraturan Presiden menetapkan bidang usaha yang tertutup untuk penanaman modal, baik asing maupun dalam negeri, dengan berdasarkan kriteria kesehatan, moral, kebudayaan, lingkungan hidup, pertahanan dan keamanan nasional, serta kepentingan nasional lainnya".
Lebih lanjut bidang usaha ini diatur oleh Peraturan Presiden Republik Indonesia Nomor 44 Tahun 2016 Tentang Daftar Bidang Usaha Yang Tertutup dan Bidang Usaha Yang Terbuka Dengan Persyaratan di Bidang Penanaman Modal.

Pada lampiran Peraturan Presiden di atas maka didapati bahwa pada Sub Sektor Energi tidak diatur mengenai kepemilikan modal, baik modal dalam negeri maupun modal asing pada sektor pertambangan batubara. Jenis bidang usaha pada sub bagian Energi hanya mengatur pembatasan kepemilikan modal asing pada sektor migas dan ketenagalistrikan (Lampiran III Peraturan Presiden Republik Indonesia Nomor 44 Tahun 2016).

b. Hak Atas Tanah

Dalam Pasal 22, Undangundang No. 25 Tahun 27 tentang Penanaman Modal mengatur tentang pembatasan pemakaian hak atas tanah oleh badan usaha maupun perseorangan. Pembatasan tersebut yaitu:

1) Hak Guna Usaha dapat diberikan dengan jumlah 95 (sembilan puluh lima) tahun dengan cara dapat diberikan dan diperpanjang di muka sekaligus selama 60 (enam puluh) tahun dan dapat diperbaharui selama 35 (tiga puluh lima) tahun;

2) Hak Guna Bangunan dapat diberikan dengan jumlah 80 (delapan puluh) tahun dengan cara dapat diberikan dan 
diperpanjang di muka sekaligus selama 50 (lima puluh) tahun dan dapat diperbaharui selama 30 (tiga puluh) tahun;

3) Hak Pakai dapat diberikan dengan jumlah 70 (tujuh puluh) tahun dengan cara dapat diberikan dan diperpanjang di muka sekaligus selama 45 (empat puluh lima) tahun dan dapat diperbaharui selama 25 (dua puluh lima) tahun.

Akan tetapi berkenaan dengan Pasal 22 Undang-Undang Nomor 25 Tahun 27 tentang Penanaman Modal di atas, Mahkamah Konstitusi telah mengeluarkan putusan berkenaan dengan Pasal 22 tersebut dalam putusan Mahkamah Konstitusi perkara Nomor 21,22/PUU-V/2007, tanggal 25 Maret 2008, menyatakan : Pasal 22 angka (1) sepanjang menyangkut kata-kata "di muka sekaligus" dan "berupa" : Hak Guna Usaha dapat diberikan dengan jumlah 95 (sembilan puluh lima) tahun dengan cara dapat diberikan dan diperpanjang di muka sekaligus selama 60 (enam puluh) tahun dan dapat diperbaharui selama 35 (tiga puluh lima) tahun.

Hak Guna Bangunan dapat diberikan dengan jumlah 80 (delapan puluh) tahun dengan cara dapat diberikan dan diperpanjang di muka sekaligus selama 50 (lima puluh) tahun dan dapat diperbaharui selama 30 (tigapuluh) tahun; dan Hak Pakai dapat diberikan dengan jumlah 70 (tujuh puluh) tahun dengan cara dapat diberikan dan diperpanjang di muka sekaligus selama 45(empat puluh lima) tahun dan dapat diperbaharui selama 25 (dua puluh lima) tahun"; Pasal 22 angka (2) sepanjang menyangkut kata-kata "di muka sekaligus"; Pasal 22 angka (4) sepanjang menyangkut katakata "sekaligus di muka";UndangUndang Nomor 25 Tahun 2007 tentang Penanaman Modal (Lembaran Negara Republik Indonesia Tahun 2007 Nomor 67, Tambahan Lembaran Negara Republik Indonesia Nomor 4724) bertentangan dengan UUD 1945.

Dalam amar putusan Mahkamah Konstitusi menyatakan : dan dapat diperbaharui selama 35 (tiga puluh lima) tahun Pasal 22 angka (1) sepanjang menyangkut kata-kata "di muka sekaligus" dan"berupa": Hak Guna Usaha dapat diberikan dengan jumlah 95 (sembilan puluh lima) tahun dengan cara dapat diberikan dan diperpanjang di muka sekaligus selama 60 (enam puluh) tahun; Hak Guna Bangunan dapat diberikan dengan jumlah 80 (delapan puluh) tahun dengan cara dapat diberikan dan diperpanjang di muka sekaligus selama 50 (lima puluh) tahun dan dapat diperbaharui selama 30 (tiga puluh) tahun; dan Hak Pakai dapat diberikan dengan jumlah 70 (tujuh puluh) tahun dengan cara dapat diberikan dan diperpanjang di muka sekaligus selama 45 (empat puluh lima) tahun dan dapat diperbaharui selama 25 (dua puluh lima) tahun".

Dalam Pasal 22 angka (2) sepanjang menyangkut kata-kata 
"di muka sekaligus"; Pasal 22 angka (4) sepanjang menyangkut katakata "sekaligus di muka"; UndangUndang Nomor 25 Tahun 2007 tentang Penanaman Modal (Lembaran Negara Republik Indonesia Tahun 2007 Nomor 67, Tambahan Lembaran Negara Republik Indonesia Nomor 4724) tidak mempunyai kekuatan hukum mengikat, sehingga Pasal 22 Undang-Undang Nomor 25 Tahun 2007 dimaksud menjadi berbunyi (Putusan Nomor 21,22/PUUV/2007, tanggal 25 Maret 2008) :

1) Kemudahan pelayanan dan/atau perizinan hak atas tanah sebagaimana dimaksud dalam Pasal 21 huruf a dapat diberikan dan diperpanjang dan dapat diperbaharui kembali atas permohonan penanam modal.

2) Hak atas tanah sebagaimana dimaksud pada angka (1) dapat diberikan dan diperpanjang untuk kegiatan penanaman modal, dengan persyaratan antara lain: penanaman modal yang dilakukan dalam jangka panjang dan terkait dengan perubahan struktur perekonomian Indonesia yang lebih berdaya saing; penanaman modal dengan tingkat risiko penanaman modal yang memerlukan pengembalian modal dalam jangka panjang sesuai dengan jenis kegiatan penanaman modal yang dilakukan; penanaman modal yang tidak memerlukan area yang luas; penanaman modal dengan menggunakan hak atas tanah negara; dan penanaman modal yang tidak mengganggu rasa keadilan masyarakat dan tidak merugikan kepentingan umum.

3) Hak atas tanah dapat diperbaharui setelah dilakukan evaluasi bahwa tanahnya masih digunakan dan diusahakan dengan baik sesuai dengan keadaan, sifat, dan tujuan pemberian hak.

4) Pemberian dan perpanjangan hak atas tanah yang diberikan dan yang dapat diperbaharui sebagaimana dimaksud pada angka (1) dan angka (2) dapat dihentikan atau dibatalkan oleh Pemerintah jika perusahaan penanaman modal menelantarkan tanah, merugikan kepentingan umum, menggunakan atau memanfaatkan tanah tidak sesuai dengan maksud dan tujuan pemberian hak atas tanahnya, serta melanggar ketentuan peraturan perundang-undangan di bidang pertanahan.

Pertimbangan

Hukum Mahkamah Konstitusi antara lain : ketentuan Pasal 22 angka (4) UU Penanaman Modal bersifat sangat eksepsional dan terbatas sehingga negara tidak lagi bebas menjalankan kehendaknya untuk menghentikan atau tidak 
memperpanjang hak-hak atas tanah sebagaimana jika perpanjangan hak-hak atas tanah itu tidak diberikan secara di muka sekaligus; pemberian dan perpanjangan hak-hak atas tanah yang diberikan sekaligus di muka tersebut juga menghambat negara untuk melakukan pemerataan kesempatan untuk memperoleh hak-hak atas tanah tersebut secara adil; pemberian hak-hak atas tanah yang "dapat diperpanjang di muka sekaligus" dalam rumusan Pasal 22 angka (1) dan angka (2) maupun kata-kata "sekaligus di muka" dalam Pasal 22 angka (4) UU Penanaman Modal telah mengurangi, memperlemah, atau bahkan dalam keadaan tertentu menghilangkan kedaulatan rakyat di bidang ekonomi dan bertentangan dengan prinsip penguasaan oleh negara.

Dengan dinyatakannya Pasal 22 Undang-undang Penanaman Modal bertentangan dengan Pasal 33 UUD 1945, ketentuan yang berlaku terhadap pemberian kemudahan dan/atau pelayanan kepada perusahaan penanaman modal untuk memperoleh hak atas tanah adalah ketentuan yang terdapat dalam peraturan perundang-undangan lainnya sepanjang berkaitan langsung dengan penanaman modal. Khusus mengenai pemberian, perpanjangan, dan pembaharuan hak-hak atas tanah (HGU, HGB, dan Hak Pakai) berlaku ketentuan Undang-Undang Nomor 5 Tahun 1960 tentang Peraturan Dasar Pokok-pokok Agraria dan Peraturan Pemerintah Nomor 40
Tahun 1996 tentang Hak Guna Usaha, Hak Guna Bangunan, dan Hak Pakai Atas Tanah.

\section{Kesimpulan}

Perusahaan harus melakukan usaha inovatif agar kontinuitas kehidupannya dapat dipertahankan yaitu melalui investasi pengembangan usaha atau lebih sering dikenal dengan sebutan ekspansi perusahaan. Ekspansi merupakan manifestasi dari keinginan untuk mempertahankan keberadaan perusahaan dalam jangka waktu yang panjang. Perusahaan tidak didirikan dengan maksud untuk berhenti setelah mendapatkan keuntungan. Ekspansi dilakukan untuk memberikan pertumbuhan bagi perusahaan. Ekspansi adalah memperbesar perusahaan baik dengan jalan mendirikan usaha baru dengan produk baru ataupun produk yang sudah ada di tempat lain ataupun juga meningkatkan produksi barang yang telah diproduksi.

Ekspansi ini sebagai salah satu tujuan dalam mempertahankan keberlangsungan hidup. Hal ini dimaksudkan sebagai bagian dari upaya untuk mencapai kehidupan perusahaan yang lebih baik dengan cara memenuhi kebutuhan konsumen. Terdapat dua motif utama suatu perusahaan melakukan ekspansi, yaitu motif ekonomi dan motif psikologi. Motif ekonomi didasarkan pada pertimbangan untuk memperbesar atau menstabilisir laba yang diperoleh. Motif Psikologis dilakukan tidak memperhatikan 
perhitungan ekonomis. Ekspansi semacam ini didasarkan pada personal ambition dari pemilik perusahaan untuk memperoleh prestige dan kekuasaan yang lebih besar. Hal yang menonjol dari motif psikologis adalah lebih didorong oleh insting atau judgement berupa keberanian untuk mengambil resiko meskipun tanpa didukung oleh pertimbangan rasionalitas yang matang.

Dalam kajian yuridis terhadap Undang-Undang Nomor 25 Tahun 2007 Tentang Penanaman Modal, penulis menemukan terdapat pembatasan ekspansi usaha kepada penanam modal yaitu menyangkut bidang usaha dan hak atas tanah. Dalam Pasal 12, Undang-undang No. 25 Tahun 2007 tentang Penanaman Modal menjelaskan bahwa : "Pemerintah berdasarkan Peraturan Presiden menetapkan bidang usaha yang tertutup untuk penanaman modal, baik asing maupun dalam negeri, dengan berdasarkan kriteria kesehatan, moral, kebudayaan, lingkungan hidup, pertahanan dan keamanan nasional, serta kepentingan nasional lainnya".

Lebih lanjut bidang usaha ini diatur oleh Peraturan Presiden Republik Indonesia Nomor 44 Tahun 2016 Tentang Daftar Bidang Usaha Yang Tertutup dan Bidang Usaha Yang Terbuka Dengan Persyaratan di Bidang Penanaman Modal. Pada lampiran Peraturan Presiden di atas maka didapati bahwa pada Sub Sektor Energi tidak diatur mengenai kepemilikan modal, baik modal dalam negeri maupun modal asing pada sektor pertambangan batubara. Jenis bidang usaha pada sub bagian Energi hanya mengatur pembatasan kepemilikan modal asing pada sektor migas dan ketenagalistrikan.

\section{Daftar Pustaka}

Arif Irwandy, 2014, Batubara Indonesia, PT. Gramedia Pustaka Utama, Jakarta.

Gazur, Wayne M., The Limited Liability Company Experiment: Unlimited Flexibility, Uncertain Role, Law and Contemporary Problems, Vol. 58, No. 2, Partnerships (Spring, 1995), Duke University School of Law.

Hayati, Tri, 2012, Perizinan Pertambangan di Era Reformasi. Pemerintah Daerah : Studi Tentang Perizinan Pertambangan Timah di Pulau Bangka, Edisi Pertama, Badan Penerbit FHUI, Jakarta.

Industri Batubara Nasional Dan Amanat Pasal 33 UUD 1945. Diakses dari http://www.berdikarionlin e.com/kabarrakyat/20111113/industribatubara-nasional-danamanat-pasal-33-uud1945.html.

Peraturan Pemerintah Nomor 40 Tahun 1996 tentang Hak Guna Usaha, Hak Guna Bangunan, dan Hak Pakai Atas Tanah.

Peraturan Presiden Republik Indonesia Nomor 44 Tahun 2016 Tentang Daftar Bidang 
Usaha Yang Tertutup dan Bidang Usaha Yang Terbuka Dengan Persyaratan di Bidang Penanaman Modal.

Putusan Nomor 21,22/PUU$\mathrm{V} / 2007$, tanggal 25 Maret 2008.

Riyanto, Bambang, 1999, Dasardasar Pembelanjaan Perusahaan, Edisi ke Empat, BPFE, Yogyakarta.

Simanjuntak, Emmy Pangaribuan, 2008, Hukum Perusahaan Kelompok dan Globalisasi Usaha (Concern), Bahan Ajar Mata Kuliah Hukum Dagang Internasional. Universitas Gadjah Mada, Yogyakarta.
Sulistiowati, 2011, "Limited Liability Dalam Limited Liability Pada Konstruksi Perusahaan Kelompok Piramida", Mimbar Hukum, Volume 23, Universitas Gadjah Mada, Yogyakarta.

Sulistiowati, 2013, Tanggung Jawab Hukum Pada Perusahaan Grup Di Indonesia, Penerbit Erlangga, Jakarta.

Undang-undang No 25 Tahun 2007 Tentang Penanaman Modal.

Undang-Undang Nomor 5 Tahun 1960 tentang Peraturan Dasar Pokok-pokok Agraria. 